\title{
Techno-economic performance of imported kukje self-propelled rice transplanter
}

\author{
M. A. Munnaf ${ }^{1^{*}}$, M. M. Hossain ${ }^{2}$ and F. Y. Ruma ${ }^{3}$ \\ ${ }^{1}$ Department of Agricultural and Industrial Engineering, Hajee Mohammad Danesh Science and Technology \\ University (HSTU), Dinajpur-5200, Bangladesh, ${ }^{2}$ Department of Farm Power and Machinery, Bangladesh Agricultural \\ University(BAU),Mymensingh-2202, Bangladesh, ${ }^{3}$ Minor Irrigation (Circle Office), Bangladesh Agricultural \\ Development Corporation (BADC), Mymensingh-2200, Bangladesh. *Email: munnaf_017@yahoo.com
}

\begin{abstract}
The experiment was conducted to study the performance of Kukje self-propelled rice transplanter and to study the economic feasibility of mechanical transplanting method over manual transplanting method. Each of the transplanting method had three unit plots of sized $20 \mathrm{~m} \times 10 \mathrm{~m}$. The field efficiency and planting efficiency of the transplanter were $83.33 \%$ and $95 \%$, respectively. Percent damaged $(3.33 \%)$ and missing $(5.33 \%)$ hills were higher in mechanical transplanting method and percent floating (4.33\%) hill was higher in case of manual transplanting method. The average labor input in mechanical transplanting was 1.4 man-day/ha where 25 man-day/ha was in case of manual transplanting. The total production costs were $53612 \mathrm{tk} / \mathrm{ha}$ and $49304 \mathrm{tk} / \mathrm{ha}$ for manual transplanting and mechanical transplanting methods, respectively. Crop established with mechanical transplanting method resulted in higher average grain yield of $6.66 \mathrm{t} / \mathrm{ha}$ than manual transplanting method resulted average grain yield of $5.83 \mathrm{t} / \mathrm{ha}$. The net return of manual and mechanical transplanting method were 42310 and $61080 \mathrm{tk} / \mathrm{ha}$, respectively. The benefit cost ratios (BCR) were 2.24 and 1.78 for mechanical transplanting method and manual transplanting method, respectively. Kukje self-propelled rice transplanter should have break-even area coverage more than $10 \mathrm{ha} / \mathrm{yr}$ for economic transplanting. The above result showed that the mechanical transplanting method is more economic than the manual transplanting method.
\end{abstract}

Keywords: Self-propelled rice transplanter, Operating cost, Crop yield, Benefit-cost ratio, Break-even point

\section{Introduction}

Rice is the staple food and the source of cash income for many Bangladeshi farmers. Bangladesh ranked fourth in respect of area and production of rice among the rice producing countries following China, India and Indonesia (FAO, 2011) and ranked $39^{\text {th }}$ in respect of world yield in rice (IRRI, 1995a). Rice production covers 77.07 percent of total agricultural production and boro rice covers 48.97 percent of total rice production (Bangladesh Agricultural Census, 2011).Moreover, the agriculture industry faces a rapid approaching labor crisis. Farm owners have been facing an acute crisis of labor in the peak time of transplanting boro paddy due to shortage of labors and excessive labor cost. The farm owners have to find the labors going door to door or they have to wait for the labors to finish the work in the nearby fields. Sometimes, they have to hire laborer offering extra wages with additional facilities. As a result, the scheduled time of transplanting paddy expires in many places. Mechanical rice transplanting is an alternative to the practice of manual transplanting and this method is faster in seedlings raising the crop. It has become popular in many countries due to its several advantages.

Mufti and Khan (1995) reported that the manual transplanting is the tedious, laborious and timeconsuming operations requiring about $250-300$ man $\mathrm{hr} / \mathrm{ha}$ which is strongly $25 \%$ of total labor requirement of rice production. They also reported that a $70 \%$ decrease in labor requirement in mechanical transplanting compared to the manual transplanting method. About 25-40 man days/ha are required to transplant with manual transplanting method where an operator with the help of an assistant can do the same work with a self propelled rice transplanter (GBK, 2012). Manjunatha et al. (2009) reported that the mechanical transplanting method would be economically covered an area of 28 ha and above in every year as well as grain yield in both manual and mechanical transplanting remained on par with mean grain yield of 53.77 and $54.01 \mathrm{q} / \mathrm{ha}$, respectively. Singh et al. (2011) reported that the cost of cultivation in both the methods was more or less or the same (Rs. 30,387/ha in traditional method and Rs. 31,750 in self-propelled rice transplanting). Chaudhary et al. (2005) stated that the self-propelled rice 
transplanter gave net profit of Rs 1146 and Rs 1319 per ha over the manual transplanting when annual use of machine was $300 \mathrm{hr}$ (one season) and $500 \mathrm{hr}$ (two seasons), respectively. They also reported the break-even area of coverage by transplanter should be more than 13.14 ha per year to make the machine transplanting profitable in comparison to the manual method of transplanting.

Kukje self-propelled rice transplanter has been imported recently from South Korea in order to meeting up the agricultural labor crisis, minimizing the production cost, increasing production per ha and attaining food security for over growing population. Before mass scale use of the transplanter to the farmer's field, its techno-economic performance study is necessary to be conducted. Considering the above background information the present research was undertaken with the following objectives: i)to evaluate the performance of Kukje self-propelled rice transplanter, ii) to study the economic feasibility of mechanical transplanting method over manual transplanting method of boro rice iii) to study the comparative yield performance for mechanical and manual transplanting methods.

\section{Materials and Methods}

The study was undertaken at the farm of Bangladesh Agricultural Development Corporation (BADC), Madhupur, Tangail during Boro seasons of 2013. The experimental field was located between $23^{\circ}$ $50^{\prime}-24^{\circ}-50^{\prime}$ North latitude and $89^{\circ}-54^{\prime}-90^{\circ}-50^{\prime}$ East longitude with $15 \mathrm{~m}$ altitude from mean sea level (MSL). The soil of the experimental plot belongs to the acidic clayey soils (Noadda and Kalma series). The experimental layout had two treatments with three replications. The total number of the unit plots was 6 and the size of the each unit plot was $20 \mathrm{~m} \times 10 \mathrm{~m}$. Kukje self-propelled rice transplanter (Details specification is shown in Table 1) and HYV BR-28 rice variety were used. According to the method used by Manjunatha et al. (2009) mat type seedlings were produced for mechanical transplanting. In case of manual transplanting, seeds were immersed in a bucket of water for 12 hours. These seeds were then taken out of water and kept in incubation for 48 hours for sprouting. Sprouted seeds were spread uniformly on the previously prepared field and pressed gently. Seedlings were watered regularly after fourth day of sowing. The land was prepared by plowing and cross-plowing with a power tiller and subsequently puddled and leveled by rotary tiller.35 days old and 28 days old seedlings were transplanted to the main field by manual and mechanical methods respectively. Relevant observations on speed of operation, time taken for turning, time taken for loading of seedling mat on to the transplanter, total time taken for transplanting, total area covered, width of coverage and fuel consumption, number of missing hills, number of damaged hills, number of floating hills of both methods were recorded.

Table 1. Specifications of the Self propelled Rice transplanter

\begin{tabular}{|c|c|}
\hline Trade name & Kukje Rice Transplanter \\
\hline Manufacturer & Kukje Machinery Co.Ltd., South Korea \\
\hline Model & KMC-750S(K) \\
\hline Engine & 4-Stroke Cycle, Air Cooled, Gasoline Engine \\
\hline Output (ps/rpm) & $5.5 / 1,800$ \\
\hline Starting method & Recoil Starter \& Electric Starter \\
\hline Working Rows & F4, R4 \\
\hline Gear shifting & Double Belt Tension Type \\
\hline Main clutch & Roller Type \\
\hline Side clutch & F4, R4 \\
\hline Rotary speed & 660 \\
\hline Wheel dia(mm) & Rubber \\
\hline Material of wheel & Ruble \\
\hline
\end{tabular}

The experimental area was fertilized with $240,150,100,60,10 \mathrm{~kg} / \mathrm{ha}$ of urea, triple super phosphate (TSP), murate of potash (MP), gypsum and zinc sulphate respectively was applied. The entire amounts of triple super phosphate, murate of potash, gypsum and zinc sulphate were applied at the time of final land preparation. Split urea was applied at the time of final land preparation, at 35 days after transplanting (DAT) and at 75DAT equally. Crop management practices such as irrigation, plant protection measures were done as per requirement and double weeding was done in order to keep the crop weed free at 30 and 65 DAT. Three randomly selected hills from each unit plot were taken as sample to record data on 
plant height $(\mathrm{cm})$, panicle length $(\mathrm{cm})$, root length $(\mathrm{cm})$, leaf length $(\mathrm{cm})$, number of total tillers/hill, number of effective tillers/hill, number of non-effective tillers/hill, hill density (hills $/ \mathrm{m}^{2}$ ), panicle density (panicles $/ \mathrm{m}^{2}$ ). The crop was harvested at the $85-90 \%$ level of maturity and the grain yield ( $\mathrm{t} / \mathrm{ha}$ ), straw yield (t/ha) and weight of 1000 grains $(\mathrm{gm})$ were also recorded with $14 \%$ moisture content than the harvesting index was calculated. Total production costs and BCR of transplanting methods were calculated and break even analysis of the transplanter was calculated. Break even point of transplanter was calculated from the following Eq.1.

Transplanting cost, $\mathrm{TC}=\frac{\mathrm{FC}}{\mathrm{X}}+\mathrm{VC}$

where,

TC $=$ Transplanting cost when transplanter was used, tk/ha

$\mathrm{x}=$ Area covered by transplanter, ha/yr

$\mathrm{FC}=$ Fixed cost of transplanter, $\mathrm{tk} / \mathrm{yr}$

$\mathrm{VC}=$ Variable cost of transplanter, tk/ha

Annual operating cost of the transplanter was calculated from the following Eq.2, (Hunt, 1995).

$A C=\frac{F C \% P}{100}+\frac{C A}{S w e}[(R \& M) P+O+L+F+T]$

where,

$A C=$ Annual operating cost of the self-propelled rice transplanter, $t \mathrm{k} / \mathrm{yr}$

$\mathrm{FC}=$ Fixed cost, tk

$\mathrm{P}=$ Purchase price of the self-propelled rice transplanter, tk

$c=$ Constant 10

$\mathrm{L}=$ Operator cost, $\mathrm{tk} / \mathrm{hr}$

$\mathrm{F}=$ Fuel cost, $\mathrm{tk} / \mathrm{hr}$

$A=$ Annual area use, $\mathrm{ha} / \mathrm{yr}$

$S=$ Forward speed, $\mathrm{km} / \mathrm{hr}$

$w=$ Effective width, $\mathrm{m}$

$e=$ Field efficiency, $\%$

$\mathrm{O}=$ Oil cost, $\mathrm{tk} / \mathrm{hr}$

$\mathrm{T}=$ Cost of tractor use by the machine, $\mathrm{tk} / \mathrm{hr}$

$R \& M=$ Repair and maintenance cost (\% of $P), t k / h r$

\section{Results and Discussion}

\section{Operational performance of the self-propelled rice transplanter over manual transplanting}

The field performances of self-propelled rice transplanter for mechanical rice transplanting over manual transplanting method shown in Table 2. Comaratively uniform hill density was obtained in mechanical transplanting as the transplanter had the adjustment mechanism of hill to hill distance and row to row distance was fixed.

Table 2. Operational performance of the self-propelled rice transplanter over manual transplanting

\begin{tabular}{|c|c|c|}
\hline Character & Mechanical transplanting & Manual transplanting \\
\hline Hill density, hill/m² & 28.00 & 27.33 \\
\hline Number of seedlings per hill & 7.80 & 5.50 \\
\hline Speed of operation, $\mathrm{km} / \mathrm{hr}$ & 1.80 & - \\
\hline Actual field capacity, ha/hr & 0.18 & - \\
\hline Theoretical field capacity, ha/hr & 0.216 & - \\
\hline Field efficiency, \% & 83.33 & - \\
\hline Labor requirement, man-hrs /ha & 11.12 & 200 \\
\hline Fuel consumption, l/hr or I/ha & 0.9 or 5 & - \\
\hline Percentage of damaged hill, $\%$ & 3.33 & 1.72 \\
\hline Percentage of missing hill, $\%$ & 5.33 & 0 \\
\hline Percentage of floating hill, $\%$ & 1.67 & 4.33 \\
\hline Planting efficiency, \% & 95 & 100 \\
\hline
\end{tabular}


The transplanting method differs considerably by the labor requirement. The total labor requirement per ha was 11.12 man-hr. (1.4 man-day) for mechanical transplanting method as against 200 man-hr. (25 man-day) in case of manual transplanting method. Due to the turning of the transplanter percent damaged $(3.33 \%)$ and missing $(5.33 \%)$ hills were higher in mechanical transplanting method and percent floating $(4.33 \%)$ hill was higher in case of manual transplanting method. Quality root system of the seedlings was troubled at the time of uprooting of seedlings from nursery. Consequently, the reduction in seedlings-mud adhesion was responsible for higher percentage of floating hills for manual transplanting method. Manual transplanting method showed $100 \%$ planting efficiency as there was no missing hill in manual transplanting method.

\section{Effect of transplanting methods on yield and yield contributing parameters}

The effects of transplanting method on grain yield and yield contributing parameters were shown in Table 3. Transplanting method strongly affected the grain yield in boro rice production. Higher the grain yield (6.66 t/ha) and straw yield (10.48 t/ha) were recorded in mechanical transplanted rice than the manual method. This might be due to proper transplanting depth, higher hill density, uniform transplanting efficiency, and lesser percentage of damaged hill and minimum percentage of hill missing in mechanical transplanting method. Mechanical transplanting produced higher effective tillers per hill (15 nos./hill) as against (13.67 nos./hill) in case of manual transplanting. Higher grain yield under mechanical transplanting method was obtained mainly due to the higher number of panicles $/ \mathrm{m}^{2}$ than that of manual transplanting method. Results showed that the transplanting methods have little or no effects on harvesting index. Similar results were also reported by Manjunatha et al. (2009).

Table 3. Effect of transplanting methods on yield and yield contributing parameters

\begin{tabular}{|c|c|c|}
\hline \multirow{2}{*}{ Plant Parameter } & Mechanical Transplanting & Manual Transplanting \\
\cline { 2 - 3 } & Average $^{*}$ \\
\hline Plant height, $\mathrm{cm}$ & 100.63 & 96.93 \\
\hline Panicle length, cm & 25.40 & 20.82 \\
\hline leaf length, cm & 52.04 & 49.62 \\
\hline Root length, cm & 18.16 & 15.67 \\
\hline Hill density, hills/m ${ }^{*}$ & 28.00 & 27.33 \\
\hline Panicle density, panicles/m & 410.00 \\
\hline Effective tillers per hill & 429.24 & 13.67 \\
\hline Non-effective tillers per hill & 15.00 & 1.33 \\
\hline Total tillers per hill & 0.33 & 15.00 \\
\hline 1000 grains weight, gm & 15.33 & 20.78 \\
\hline Straw weight per hill, gm & 21.21 & 31.30 \\
\hline Grain yield, $\mathrm{kg} / \mathrm{ha}$ & 37.50 & 5825 \\
\hline Straw yield, $\mathrm{kg} / \mathrm{ha}$ & 6660 & 8548 \\
\hline Harvesting index & 10483 & 0.40 \\
\hline
\end{tabular}

${ }^{*}$ Average value taken from three replications of each method

\section{Effect of transplanting methods on production costs}

Item wise costs of crop establishment and total production costs are shown in Table 4. It was noticed that the land preparation, irrigation, weeding, fertilizer, harvesting and threshing costs were same for both methods. Seed cost and transplanting cost varied depending upon the transplanting method. Seedlings cost was 2652 tk/ha for manual transplanting method and 3243 tk/ha for mechanical transplanting method.

Table 4. Effect of transplanting methods on production costs

\begin{tabular}{|c|c|c|}
\hline Operation & \multicolumn{2}{|c|}{ Production cost, tk/ha } \\
\cline { 2 - 3 } & Mechanical & 2652 \\
\hline Seedling raising & 3243 & 7410 \\
\hline Land preparation & 7410 & 7500 \\
\hline Transplanting to the main field & $2601^{*}$ & 36050 \\
\hline $\begin{array}{c}\text { Fertilizer, Irrigation, Hand weeding, Pest control, } \\
\text { Harvesting and Threshing }\end{array}$ & 36050 & 53612 \\
\hline Total & 49304 & \multicolumn{2}{|c|}{} \\
\hline
\end{tabular}

*Calculated from annual operating cost of transplanter considering $129.6 \mathrm{ha} / \mathrm{yr}$ area coverage and actual field capacity $0.18 \mathrm{ha} / \mathrm{hr}$. 
Transplanting cost for manual transplanting method (7500 tk/ha) was higher than the mechanical transplanting cost (2601 tk/ha). The total production cost was 53612 tk/ha and 49304 tk/ha for manual transplanting method and mechanical transplanting method respectively.

\section{Effect of transplanting methods on total cost, gross return and net return}

The gross return was calculated based on the then market price of paddy and straw. Effect of transplanting methods on total cost, gross return and net return were shown in Table 5 . The gross return were $110383 \mathrm{tk} / \mathrm{ha}$ and $95923 \mathrm{tk} / \mathrm{ha}$ for mechanical and manual transplanting method, respectively. The net return from mechanical transplanting method was higher $(61079 \mathrm{tk} / \mathrm{ha})$ as against the net return $(42311 \mathrm{tk} / \mathrm{ha})$ in case of manual transplanting method. From these results it could be concluded that $18768 \mathrm{tk} / \mathrm{ha}$ will be more profitable for mechanical transplanting method over the manual transplanting method. It was observed that the BCR (2.24) of mechanical transplanting method was higher by $25.8 \%$ than the BCR (1.78) of manual transplanting method. The lower BCR was obtained in the manual transplanting method due to higher labor cost and higher seed rate.

Table 5. Effect of transplanting method on total cost, gross return and net return

\begin{tabular}{|c|c|c|}
\hline Returns & Mechanical transplanting & Manual transplanting \\
\hline Return from grain yield*, tk/ha & 99900 & 87375 \\
\hline Return from straw yield**, tk/ha & 10483 & 95923 \\
\hline Gross return, tk/ha & 110383 & 42311 \\
\hline Net return, tk/ha & 61079 & 1.78 \\
\hline BCR & 2.24 & \\
\hline
\end{tabular}

${ }^{*}$ Grain yield $15 \mathrm{tk} / \mathrm{kg},{ }^{* *}$ Straw yield $1 \mathrm{tk} / \mathrm{kg}$

\section{Break even analysis}

Operational cost of mechanical transplanting was worked out for different number of ha usage during a year, as the cost per ha varies with the number of ha usage in a year of the machine. Variation of cost/ha with number of ha of usage per year is shown in Fig. 1.

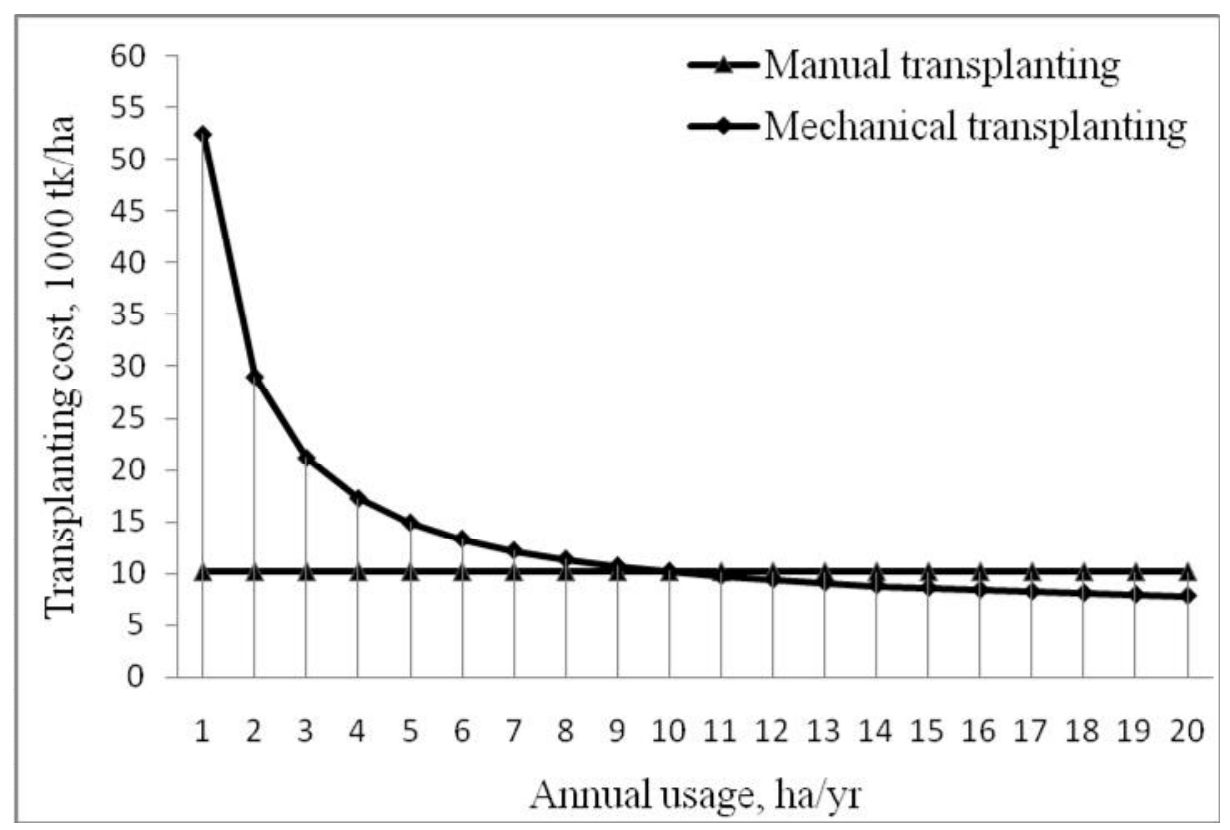

Fig. 1. Effect of annual usage on transplanting cost 
The maximum possible coverage area $129.6 \mathrm{ha} / \mathrm{yr}$ was predicted by taking into account the actual field capacity of $0.18 \mathrm{ha} / \mathrm{hr}$, three seasons per year with 30 days of transplanting period per season and taking $8 \mathrm{hr}$ of working per day. The cost of transplanting through mechanical transplanter was $5843 \mathrm{tk} / \mathrm{ha}$ as against $10152 \mathrm{tk} / \mathrm{ha}$ in case of manual transplanting at the maximum annual area coverage. Manual transplanting cost was $10152 \mathrm{tk} / \mathrm{ha}$ and the cost of mechanical transplanting would break even at 10 ha of usage per year. If the usage of the machine is less than 10 ha in a year, the cost of operation would be more than manual operation.

\section{Conclusion}

The performance of the Kukje self-propelled rice transplanter was quite satisfactory and the labor requirement was 1.4 man days per ha as against 25 man days per ha in case of manual transplanting. The mechanical transplanting would be economical if it is used to cover an area of 10 ha or above per year. Thus, it is possible to increase the production per ha and to reduce the cost of paddy transplanting by mechanization to almost half the cost of manual transplanting provided the machines are used for their maximum ha usages in a year. Like all other wetland agricultural machinery, the Kukje self-propelled rice transplanter also has the problems of sinking in black soils and requires skilled operator. Hence, there is need to quantify the intensity of puddling and sedimentation period so as to give sufficient bearing capacity to the soft puddle soil to prevent sinking or floating of transplanter and it is also essential to build up skilled operator.

\section{Acknowledgements}

The authors would like to thank the Bangladesh Agricultural Development Corporation (BADC) and the Golden Barn Kingdom of Bangladesh (GBK) for providing the experimental field and machinery facilities for this research.

\section{References}

Bangladesh Agricultural Census 2011. Bangladesh Bureau of Statistics, Government of the People's Republic of Bangladesh. Ministry of Planning, Dhaka.

Chaudhary, V.P., Varshney, B.P. and Kalra, M.S. 2005. Self-Propelled rice transplanter- a better alternative than manual transplanting, Agricultural Engineering Today, $29: 32$ - 37.

FAO (Food and Agricultural Organization). 2011. Country ranked in respect of area and production of rice, http//www.faostat.fao.org/site/567/default.aspx. For economizing labour, indian fmg., $54: 23$ - 25.

GBK (Global Barn Kingdom). 2012. A presentation on harvesting the potentialities of world-standard rice production technologies for transforming Bangladesh into rice-exporting country, Pantha Path, Dhaka.

Hunt, D. 1995. Farm Power and Machinery Management, Cost Determination. 9th ed, Lowa State University Press, America.

IRRI (International Rice Research Institute) 1995(a). World Rice Statistics 1993-94 Los Banos, Philippines.

Manjunatha, M.V., Masthana, B.G., Shashidhar, S.D. and Joshi, V.R. 2009. Studies on the performance of self-propelled rice transplanter and its effect on crop yield. Karnataka J. Agric. Sci., 22(2 ) : 385 - 387.

Mufti, A.I. and Khan, A.S. 1995. Performance evaluation of Yanmar paddy transplanter in Pakistan. Agricultural mechanization in Asia, Africa and Latin America, 26(1) : 31 - 36.

Singh, R.S. and Rao, K.V.R. 2011. Impact of self propelled paddy transplanter in Kerala. Nabibagh, India. 